\title{
第36回日本老年医学会総会記録
}

\section{<教育講演 $>$}

\section{老年者の大腿骨頝部骨折 \\ 一2000骨折について一}

\author{
五十嵐三都男
}

Key words : 老年者, 大腿骨頸部骨折, 2000骨折, 外傷の無い骨折, 余命

(Jpu J Gariat $1995 ； 15$-19.)

\section{1.はじめに}

老年者の骨折で最も頻度が高いのは脊椎椎体骨折で あるが，それにつぐのが大腿骨頸部骨折である。椎体 骨折は腰背痛として表現されるが，臥床するにしても そう長期間ではない，それに対して，大腿骨頸部骨折 では, 臥床のみで回復し元の様に活躍することは非常 に稀である，大腿骨頸部骨折は出血量が多いので，合 併症の多い老年者では全身への影響が大きく, 早期の 積極的治療によって早くからのリハビリテーションを 行わなければならない. 保存療法では生命への危険性 が非常に高くなる。

\section{2. 症例}

1972 年 4 月より 1993 年 3 月迄の 12 年間に当科で治療 した大腿骨頸部骨折 2,000 件について調査をし,それを もとに報告する. 全例からの情報が得られなかった項 目については部分的症例について報告する。症例構成 は表 1 に示す. 女性がはるかに多く, 男女比は 1 対 4 である. 平均年齢は女性の方が2.6歳高い.ここで示し ているのは骨折件数であるが, 患者数では 1,884 人であ る.ただし両側を同時に骨折した症例は 2 件とせず, 便宜上 1 件として数えた。骨折を全て数え上げれば 2,004件である.

表 2 に示すように, 両側同時骨折が 4 例 8 骨折ある. 表 3 には同一人が複数回骨折を起こした数を示す。 2 回骨折を起こした人が 108 人であり，骨折数 216 件. 3 回骨折を起こした人が 4 人であり, 骨折数 12 件.

図 1 に年齢分布を示す.中央值は男性79歳, 女性 81 歳であり, 平均年齢に等しい.

2000 femoral neck fractures of the aged.

M. Igarashi：東京都老人医療センタ一整形外科
表 1 大腿骨頝部骨折症例（1972年 4 月-1993年 3 月）

\begin{tabular}{c|r|c|c|c}
\hline & 合計 & 平均年柃 & 標準偏差 & 年齢範囲 \\
\hline 男 & 390 & 78.6 & 7.87 & $52-100$ \\
女 & 1,610 & 81.2 & 7.47 & $50-102$ \\
\hline 合計 & 2,000 & 79.9 & 7.58 & $50-102$ \\
\hline \multicolumn{4}{|c}{ 両側同時骨折は 1 件として記載 } \\
総患者数 1,884人 総骨折数 2,004件
\end{tabular}

表 2 両側同時骨折

\begin{tabular}{ll}
\hline 4 例 & $61,65,85,86$ 歳 \\
全例 & 女性. \\
骨折型 & $1:$ 内側, 外側 \\
& $2:$ 内側, 内側 \\
& $3:$ 内側, 外側 \\
& $4:$ 外側, 外側 \\
\hline
\end{tabular}

表 3 複数回骨折

\begin{tabular}{lrr}
\hline 総数 & 112 人 & \\
総骨折数 & 228 件 & \\
2 回骨折 & 108 人 & 216 件 \\
3 回骨折 & 4 人 & 12 件 \\
\hline
\end{tabular}

\section{3. 受傷と入院}

受傷機転は図 2 に示すように圧倒的多数は転倒であ る。転落は 2 位であるがはるかに少なくなる． 3 位の 不明には痴呆のために状況がつかめなかったものも含 まれる，4位に受傷機転なしが来るが，これは歩行中 に股関節部がぎくっとして歩行不能になったという様 な, 全くの外傷無しを意味する．この点に関しては後 に述べる.

受傷より入院までの日数を図 3 に示す. 中央值が 3 日であり, 半数がこれまでに入院した. 11日までに $3 /$ 


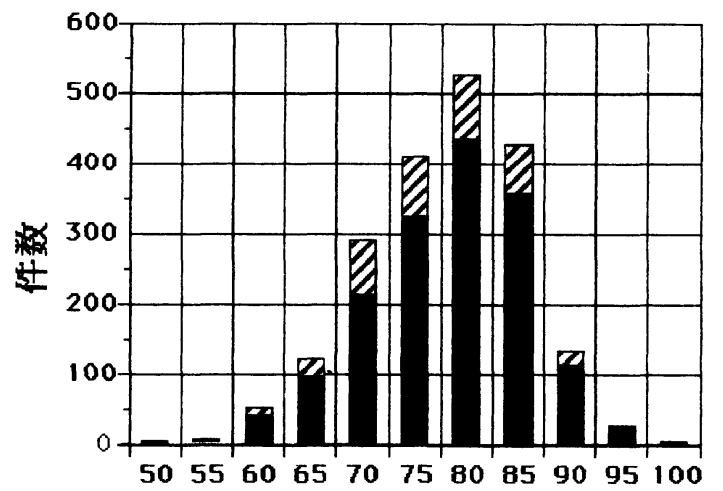

年䤅

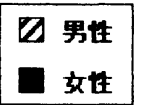

図 1 年柃分布

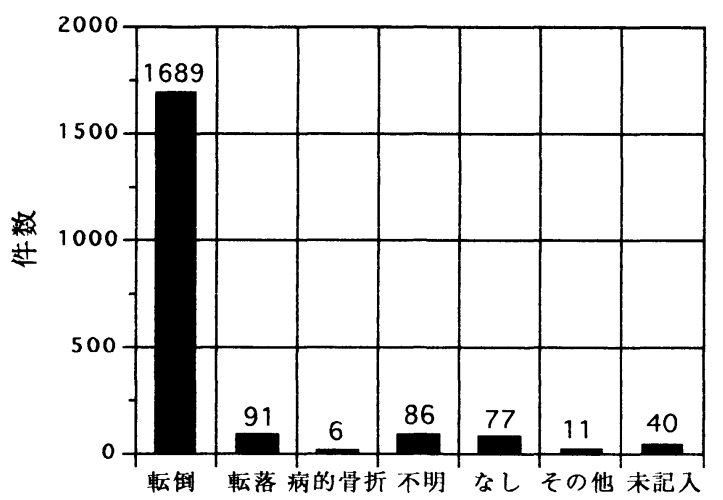

図 2 受傷状況

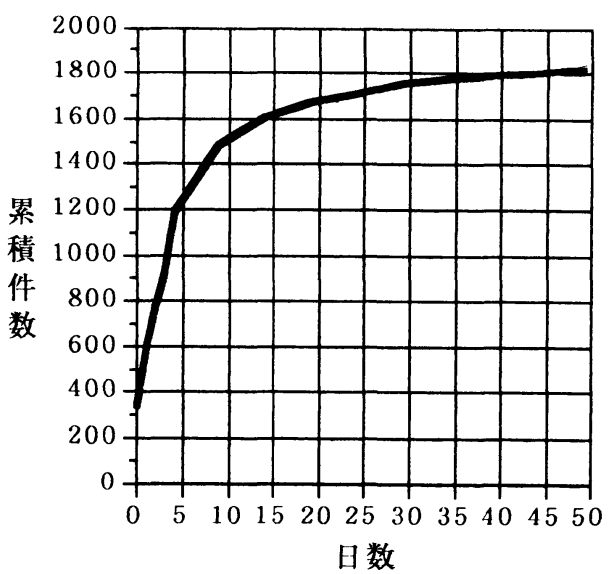

図 3 受傷より入院までの日数

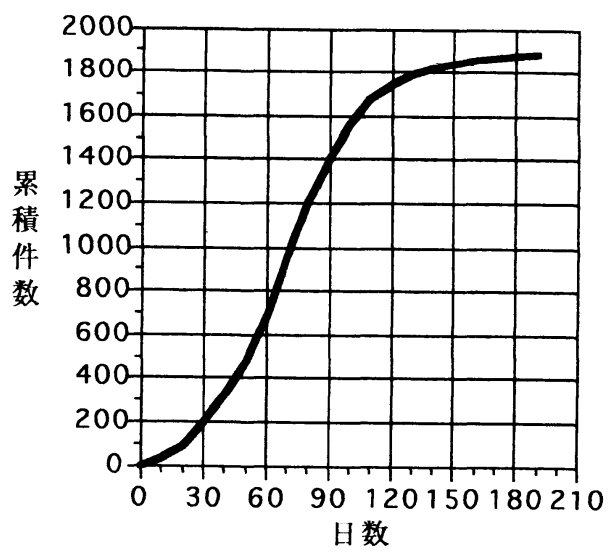

図4 入院日数

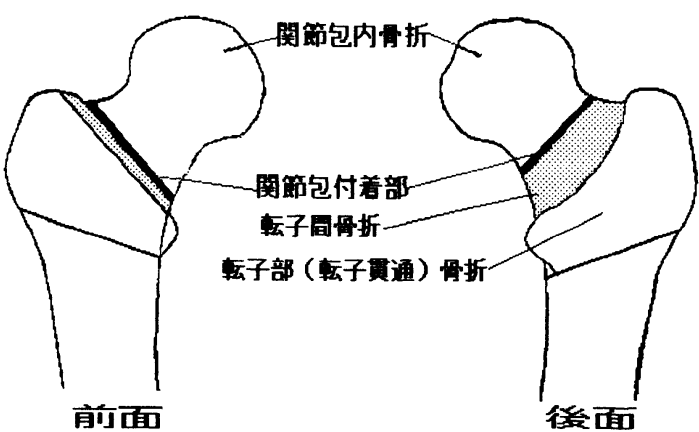

図 5 大腿骨頸部骨折の分類

4 が入院した．図 4 に入院日数を示す．入院日数の中 央値は70日. 半数の人は 70 日で退院した。 $3 / 4$ の人は 92日で退院した。

\section{4. 大腿骨頸部の解剖学的特異性}

図 5 に示すように，大腿骨頸部骨折は関節包付着部 を境にして関節包内骨折（内側骨折）と関節包外骨折 (外側骨折)に 2 大別される. 関節包付着部と転子部と の間はやや特殊な振るまいをするので, 細分されて転 子間骨折と呼ばれる。

この分類は骨頭を栄養する血管の走行が特殊である 為による. 図 6 に示すように medial femoral circumflex vessel の枝の superior と inferior retinacular vessel が関節包付着部より骨頭内にはい るが，これでほとんどの栄養を受けている。 medial epiphyseal vessel は欠如していることもあり，あって も骨頭のごく一部に関与しているのみである，関節包 内で骨折を起こすと骨頭を栄養する血管が絶たれてし まい，骨壊死になる可能性が高くなる。また関節包内 


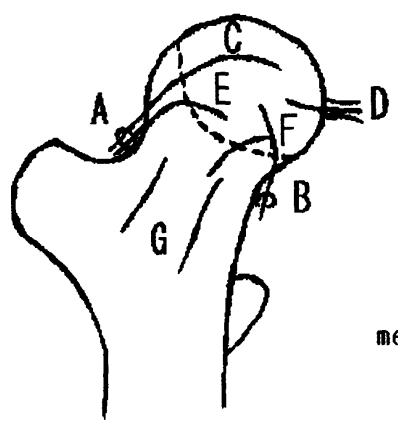

図 6 大腿骨頭の血流

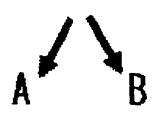

A. superior retinacular vessels

B. inferior retinacular vessels

C. lateral epiphyseal vessels

D. medial epiphyseal vessels

E. superior metaphyseal vessels

F. inferior metaphyseal vessels

G. int ramedul lary vessels

medial femoral circumflex ressels

の頸部には骨膜が存在しないので骨折治癒に重要な骨 膜性骨新生が起こらない欠点がある，更にこの部は関 節液中にあるので，骨折の治癒過程である血腫形成・ 肉芽形成・化骨形成がみられない. 内側骨折は治癒過 程に大きなハンディキャップを負っている.

\section{5. 大腿骨頸部骨折の分類と治療}

表 4 に示すのが骨折型の内訳である. 外側骨折の方 が多く, かつ平均年齢も高い. 初めに症例の内訳でも 少し述べたが，両側同時骨折は 4 例あり，共に内側骨 折 2 例, 共に外側骨折 1 例, 内側と外側骨折 1 例であっ た。両側同型骨折はその骨折型に入れた。両側同時内 側と外側骨折はこの表には入れていない.

内側骨折 831 件の内 807 件は頸部骨折であり, 骨頭骨 折はなかった。外側骨折 1,168 件の内 1,039 件は転子部
骨折であった.内側骨折は Garden の分類, 外側骨折は Jensennの分類に従ったが，各分類の中でどの型に大 きく片寄るということはなかった. 内側骨折の治療に は601件が人工骨頭によった。139例の保存療法は全て Garden の stage 1である外転骨折である. 外側骨折の 治療方法は初期には Jewett nail plateにより，その後 現在までCompression hip screw plateにより行われ 合計988件である.

内側と外側骨折の割合を男女についてもう少し詳し く見ると, 図 7 のごとくである.男性では内側骨折/外 側骨折の割合が $28 \%$ から $54 \%$ の間でそう大きく変動し ないのに対して,女性では70歳未満の $134 \%$ から年蔽の 増加と共に次第に隇少し 90 歳以上の $40 \%$ となり男性並 となる，骨粗鬆症と関係があると思われるのだが,こ の原因についてはうまく説明できない.

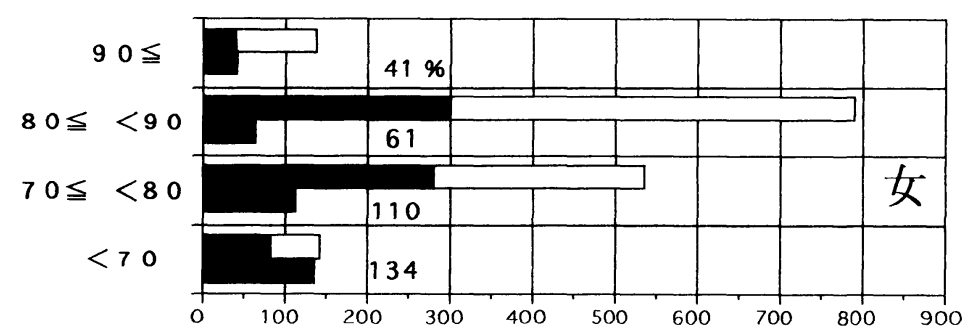

年龄

件数
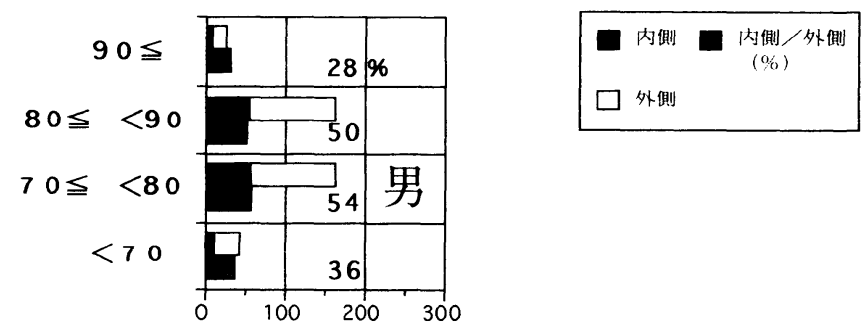

図 7 骨折型による分類と比率 
表 4 大腿骨頝部骨折型による分類

\begin{tabular}{c|c|c|c|c|c|c}
\hline & 計 & 男 & 女 & 平均年齢 & 標準偏差 & 年齢範囲 \\
\hline 内側骨折 & 831 & 127 & 704 & 78.6 & 7.43 & $52-99$ \\
外側骨折 & 1,168 & 263 & 905 & 80.7 & 7.56 & $50-102$ \\
\hline 合 計 & 1,999 & 390 & 1,609 & & & \\
\hline \multicolumn{7}{c}{ その他 1 例 \{両親(内側, 外側)骨折 \} } \\
両側同時同型骨折は 1 件と記載
\end{tabular}

表 5 外傷のない大腿骨頝部骨折

\begin{tabular}{lll}
\hline 総数 78 件 74 人 & \\
(再側同時骨折 1 人, 反対側再骨折 3 人) \\
男 2 件 & 77,83 歳 \\
女 76 件 & 平均年齢 & $80 \pm 6.8$ 歳 \\
右 35 件 & & \\
左 43 件 & (両側 1 人 $(2$ 件) ) \\
内側骨折 & 72 件 \\
外側骨折 & 6 件 \\
\hline
\end{tabular}

表 6 大腿骨頝部骨折 外傷ありと外傷なしの比較

\begin{tabular}{l|c|c}
\hline & 外傷なし & 外傷あり \\
\hline 数(骨折) & 40 & 40 \\
性 & 女 性 & 男 性 \\
年齢範囲 & $91-64$ & $91-64$ \\
平均 & 79.2 & 79.2 \\
標準偏差 & 6.9 & 7.0 \\
\hline \multicolumn{3}{r}{} \\
\multicolumn{3}{|c}{ 内側骨折 37} \\
外側骨折 3
\end{tabular}

\section{6. 外傷の無い骨折}

骨折の原因は外傷が普通であるが，表 5 のごとく $3.9 \% 78$ 骨折 74 人に外傷が全く無いことが確認された 骨折がみられた。痴呆がみられる例が多いので確認が 難しい.したがって実際はこの数より多いと思われる. 男性より女性と外側骨折より内側骨折の方が圧倒的に 多い. 反対側再骨折の 3 人の骨折は初回と 2 回目と共 に外傷無しの骨折であった。

この様に外傷が無い骨折の原因は何であろうか. 総 骨折 1,500 件の時に調査した ${ }^{11}$. 表 6 に示すようにその 他の外傷のある症例より性・年齢・骨折型・全身状態 の一致した40例を無作為に選んで比較した. Singh index により大腿骨頸部の骨粗鬆症の程度を比較した のを表 7 に, spinal score で脊椎の骨粗鬆症の程度を 比較したのを表 8 に示す。いずれにおいても外傷の無 い大腿骨頸部骨折は，外傷のある症例よりも骨粗鬆症
表 7 Singh Index による大腿骨頝部の骨粗鬆症

\begin{tabular}{c|c|c|r|r|c|c|c}
\hline Singh Index & 6 & 5 & \multicolumn{1}{|c|}{4} & \multicolumn{1}{|c|}{3} & 2 & 1 & $\mathrm{n}$ \\
\hline 外傷なし & 0 & 1 & 5 & 8 & 19 & 7 & 40 \\
外側あり & 0 & 0 & 11 & 10 & 19 & 0 & 40 \\
\hline
\end{tabular}

$\mathrm{p}<0.05$ (Wilcoxon test)

表 8 Spinal Score による脊髄骨粗鬆症

\begin{tabular}{c|r|r|r|r|r|r|r|r|r}
\hline Spinal Score & 8 & \multicolumn{1}{|c|}{7} & \multicolumn{1}{|c|}{6} & 5 & 4 & 3 & 2 & 1 & $\mathrm{n}$ \\
\hline 外傷なし & 15 & 11 & 3 & 5 & 1 & 0 & 0 & 0 & 35 \\
外側あり & 6 & 8 & 10 & 9 & 2 & 0 & 0 & 0 & 35 \\
\hline
\end{tabular}

$\mathrm{p}<0.01$ (Wilcoxon test)

表 9 大腿骨頝部骨折の合併症（例数）

\begin{tabular}{lr|lr}
\hline 痴呆 & 296 & パーキンソニズム & 47 \\
高血圧 & 240 & 変形性関節症 & 45 \\
脳血管障害 & 147 & 慢性関節リウマチ & 41 \\
視力障害 & 98 & 裉哌 & 40 \\
呼吸器疾患 & 83 & 聴力障害 & 36 \\
心疾患 & 83 & 血液疾患 & 30 \\
膀胱炎 & 80 & 腎機能障害 & 21 \\
糖尿病 & 78 & 肝機能障害 & 20 \\
消化器疾患 & 53 & その他 & 226 \\
\hline
\end{tabular}

1,009骨折調查時

は有意に高度である.この様に骨粗鬆症が亢進すると， 大腿骨の様な骨まで, 脊椎圧迫骨折の様に日常の生活 の中で大きな機転も無く骨折を起こすようになる.

\section{7. 合併症}

平均年齢80歳ほどの老年者群が大腿骨頸部骨折の症 例であるので当然ながら種々の合併症を持っている. 表 9 に1,009骨折時の調査を示す2). 痴呆・高血圧・脳 血管障害が第 1 位から 3 位までの主要合併症である。 ある疾患が存在するとする診断境界をどの様にとるか によって数に変化がでてくるが，概略の傾向はこのよ うなものである。

\section{8. 片麻㽽と骨折}

片麻痺側に大腿骨頸部骨折を引き起こすことはよく みられる，表10は麻痺側の骨折は本当に多いのかどう かを調べた結果である ${ }^{3)}$. 1,691骨折中明らかな片麻瘏 のあった 181 骨折のうち右片麻痺側の骨折 $85 \%$, 左片麻 痺側の骨折 $68 \%$ であり，1\%以下で有意に麻痺側に骨 折が多い. 
表10 片麻痺と大腿骨䅡部骨折

\begin{tabular}{c|c|c|c}
\hline & 右骨折 & 左骨折 & 計 \\
\hline 右片麻疩 & 77 & 14 & 91 \\
左片麻疩 & 29 & 61 & 90 \\
\hline 計 & 106 & 75 & 181 \\
\hline \multicolumn{3}{|c}{$\mathrm{p}<0.01$}
\end{tabular}

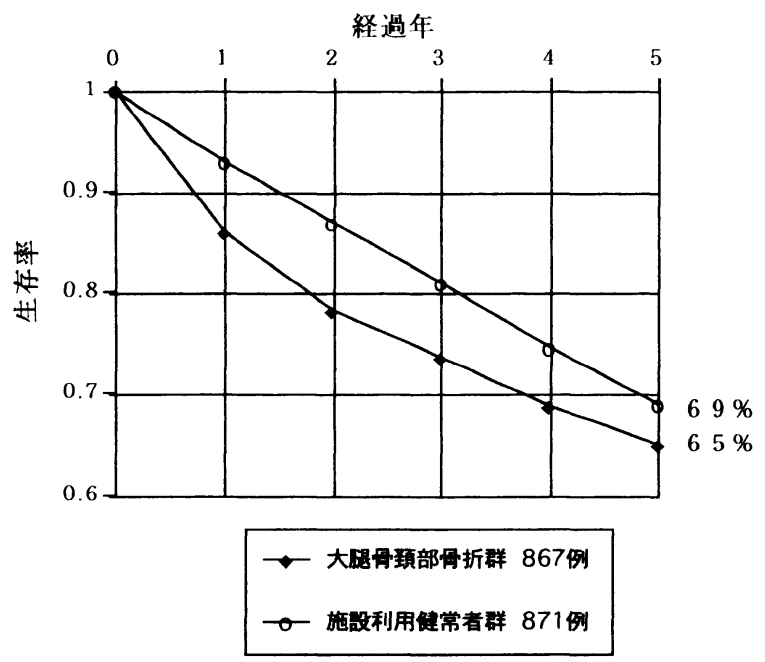

図 8 大腿骨頸部骨折群と施設利用健常者群の生存曲 線

\section{9. 骨折と余命}

骨折後数力月以内の死亡率は高くなるが，それ以後 の死亡率は骨折しない老年者と同等であるという発表 はある.図 8 は大腿骨頸部骨折 1,084 名の内追跡調査可 能であった 867 名 (平均年齢78.8歳) と東京都養育院老
人ホーム居住老年者 871 名 (平均年齢78.3歳) の調查結 果である ${ }^{4)}$. 骨折後 1 年以内に, 骨折例は $14 \%$, 非骨折 例は $6 \%$ 生存率が低下するが 5 年後においては $4 \%$ の 差であった。骨折直後を無事乗切った人は, 骨折を起 こさなかったように生存できることを示している.

\section{0. まとめ}

老年者の大腿骨頸部骨折は骨粗鬆症を基盤に転倒に よって起こる．多彩な合併症を持つ老年者では転倒を 予防することは難しい．大腿骨頸部骨折は出血量が多 いので全身への影響が大きく，かつ大腿骨頸部の解剖 学的特異性により治療が難しい.しかし, 全身管理を 十分にして早期に積極的治療を行えばその治療成績は 良い。

\section{文献}

1) Horiuchi $T$, Igerashi $M$, Karube $S$, Oda $H$, Tokuyama H, Huang $\mathrm{T}$, et al: Spontaneous fractures of the hip in the elderly. Ortopedics $1988 ; 11: 1277-1280$.

2）軽部俊二, 五十嵐三都男, 林 泰史, 井上 茂, 織 田弘美，劉 有漢：高齢者の大腿頸部骨折 1009 例 の治療経験. 整形・災害外科 $1985 ; 28: 473-478$.

3）斉藤昭彦, 五十嵐三都男, 軽部俊二, 岩野孝彦, 横 関 仁, 䀈尾 茂：片麻痺患者と大腿骨頝部骨折. 東日本臨整会誌 $1991 ; 5: 106-109$.

4）七田恵子, 遠藤千恵子, 柴崎公子, 軽部俊二, 織田 弘美, 他: 大腿骨䅡部骨折患者の追跡調査一生存 率と身体的活動性一. 日老医誌 $1988 ; 25: 563-$ 568 . 